\title{
IAIN Sorong 2020: Mimpi yang Terwujud
}

\author{
Ismail Suardi Wekke \\ Sekolah Tinggi Agama Islam Negeri (STAIN) Sorong \\ Email: iswekke@gmail.com
}

\begin{abstract}
ABSTRAK
Artikel ini merupakan paduan antara harapan dan juga agenda STAIN Sorong ketika pada saatnya beralih status menjadi IAIN. Harapan dipundakkan ke STAIN Sorong di tengah-tengah dinamika kebangsaan menghadapi merebaknya rasisme dan juga berita bohong yang menjadi komsumsi seharihari. Perguruan tinggi justru melampau semua itu dengan senantiasa menatap masa depan.
\end{abstract}

Kata Kunci: pendidikan tinggi; perguruan tinggi; pendidikan keagamaan.

\section{Pendahuluan}

Perguruan tinggi menjadi dinamisator keberadaan masyarakat. Maka dengan menjadi perguruan tinggi berarti kesediaan menjadi katalisator juga bagi masyarakat. Dengan menggunakan triple helix (Etzkowitz \& Zhou, 2017), perguruan tinggi akan membawa masyarakat untuk senantiasa hidup di masa kini yang akan berlanjut di masa depan. Bukan dengan belajar tentang masa lalu dan berhenti di masa kini. Berikut ini impian yang memungkinkan untuk diwujudkan ketika pada saatnya IAIN Sorong wujud.

Curah gagasan ini menjadi bagian dalam mengantar STAIN Sorong untuk bersiap menuju IAIN Sorong. Sebagaimana paparan sebelumnya tentang integrasi sains dan agama (Abbas \& Wekke, 2019), transformasi perguruan tinggi keagamaan (Mujahidah \& Wekke, 2019), penyiapan untuk alih status (Wekke, 2019), budaya perguruan tinggi (Mulyono \& Wekke, 2018), peran perguruan tinggi di wilayah minoritas muslim (Wekke, 2018), teaching and learning in higher education (Wekke, 2017; Kuraedah, Gunawan, Wekke, \& Hamuddin, 2018), respon perguruan tinggi terhadap bencana (Wekke, Rajindra, Pushpalal, Samad, Yani, \& Umam, 2019). Kesemuanya menggambarkan bahwa perguruan tinggi menjadi bagian masyarakat yang dapat diartikulasi sesuai dengan keperluan masyarakat yang ada di wilayahnya.

\section{Mimpi yang Terwujud di IAIN Sorong}

Saat IAIN Sorong diresmikan Presiden Republik Indonesia, Bapak Jokowi Widodo, didampingi Kabinet Kerja II yag dihadiri Menteri Agama RI, Menteri Riset, Teknologi, dan Pendidikan Tinggi RI, maka saat itu juga STAIN dimana hanya pada pembidangan keilmuan secara spesifik ditinggalkan. Dengan status IAIN akan menjadikan pola keilmuan pokok yang terkait dengan antardisiplin. Setiap bidang ilmu saling menyapa dengan ilmu lain. Sehingga terbentuk niche antarbidang. Bahkan setiap niche berada dalam jaringan kelompok peneliti yang 
berada di pusat-pusat kecemerlangan antarbangsa. Kondisi ini memberikan solusi bagi masalah yang timbul di masyarakat Papua. Setiap masalah atau gejala sosial dijadikan sebagai wacana di IAIN Sorong, dan selanjutnya memberikan usulan-usulan solutif untuk penyelesaian masalah.

Kehadiran Presiden RI bersama Gubernur Papua Barat dan Majelis Rakyat Papua Barat meresmikan IAIN Sorong sekaligus peletakan batu pertama pengembangan kampus dua yang semuanya dengan infrastruktur yang mutakhir. Bahkan jaringan internet sudah menggunakan 5G. Kementerian Pekerjaan Umum dan Perumahan Rakyat RI sebagai pelaksana teknis yang dimandat Presiden RI untuk menyelesaikan pembangunan. Tidak saja kampus, tetapi juga menjadi kawasan pendidikan baru di Tanah Papua. IAIN Sorong sekaligus mengelola sekolah mulai dari Madrasah Ibtidaiyah sampai ke Madrasah Aliyah. Sehingga mahasiswa dapat mempraktikkan teori dan pengetahuan yang didapatkan di kelas-kelas untuk langsung beradaptasi dengan realitas kelas. Bukan saja menjadi madrasah laboratorium tetapi juga menjadi madrasah model. Dimana dosen IAIN Sorong sekaligus menjadi bagian yang terintegrasi dalam pengelolaan madrasah. Mengakhiri sambutan Presiden RI, diserahkan Keputusan Presiden tentang Akselerasi Perguruan Tinggi Papua dalam pengembangan kapasitas kelembagaan pada 2024 IAIN Sorong wujud menjadi UIN Sorong.

Bahkan terdapat program akselerasi. Dimana siswa madrasah sudah mulai diperkenalkan kurikulum yang ada di IAIN Sorong. Sehingga mereka tidak perlu masuk ke tahun pertama tetapi bisa jadi langsung ke semester tertentu setelah dilakukan evaluasi. Dua tahun terakhir di madrasah sudah mulai dilakukan komunikasi antara guru dengan dosen untuk memberikan kesempatan kepada setiap siswa yang memiliki kemauan dan kemampuan sekaligus untuk menempuh jenjang akselerasi. Sehingga di bangku kuliah cukup dengan waktu tiga tahun saja.

Mahasiswa pada tahun pertama wajib untuk mukim di ma'had. Mereka mendapatkan pengayaan bahasa asing, Arab-Inggris-Mandarin. Ketiga bahasa ini akan menjadi bekal dalam penjelajahan ilmu pengetahuan dan juga pada saat menyelesaikan pendidikan sarjana. Ketika itu, setiap mahasiswa yang sudah registrasi ulang saat mengikuti Orientasi Pengenalan Akademik Kampus (OPAK) akan mengikuti sesi belajar materi penggunaan alat-alat untuk menunjang aktivitas belajar seperti Mendeley atau Zotero. Secara berkala, baik diintegrasikan dalam perkuliahan maupun aktivitas pelatihan yang secara khusus terjadwal. Kemampuan riset ini menjadi bekal mahasiswa bahkan sebelum duduk di hari pertama kuliah. Kemampuan menggunakan tools riset dan publikasi menjadi capaian pembelajaran yang tercantum dalam Surat Keterangan Pendamping Ijazah (SKPI). Sehingga alumni IAIN Sorong dengan tetap berpijak pada kearifan lokal, juga pada saat yang sama berwawasan global. 
Adapun dosen mengajarkan temuan-temuan riset yang dilakukan setahun terakhir. Tidak saja meneliti dalam topik mata kuliah yang ditelitinya tetapi bisa saja menyapa tema lain sesuai dengan rumpun keilmuan agama Islam. Setiap dosen memublikasikan penelitiannya di jurnal yang bereputasi. Demikian pula menulis buku ajar sesuai mata kuliah yang diampuh. Sehingga karya dosen tidak saja disitasi oleh mahasiswanya tetapi juga mendapat rekognisi antarbangsa. Termasuk kesempatan dosen IAIN Sorong untuk menjadi dosen tamu di pelbagai perguruan tinggi yang sudah bertaraf World Class University. Bagi dosen yang sudah menyelesaikan pendidikan doktor, mereka secara terjadwal berpartisipasi dalam sabbatical leave untuk meneliti dan menulis dengan bersinergi bersama dosen-dosen di perguruan tinggi terkemuka.

Bangunan yang terlihat menunjukkan kekhasan Papua. Demikian pula setiap bangunan ramah terhadap penyandang disabilitas. Juga mengaplikasikan prinsip teknologi hijau sehingga penggunaan energi tidak boros. Sekaligus setiap atap bangunan tersedia instrumen Pembangkit Listrik Tenaga Surya (PLTS). Sehingga 60\% keperluan listrik disediakan secara mandiri dengan perangkat PLTS.

Ornamen-ornamen yang wujud di setiap bangunan merupakan cerminan seni dari setiap suku yang ada di Tanah Papua. Bahkan mata kuliah Antropologi Budaya Papua diajarkan dengan 4 SKS selama dua semester. Kesempatan menempuh kuliah ini juga dilengkapi dengan Summer School on Papua Heritage. Setiap jeda semester genap ke semester ganjil, mahasiswa asing diundang untuk mengikuti program budaya Papua. Mereka bahkan punya kesempatan untuk menjelajahi hutan-hutan wisata sebagai pengenalan terhadap ekologi Papua.

Noken sebagai wawasan kebudayaan Papua tidak saja menjadi bagian pembahasan dalam mata kuliah Antropologi Budaya Papua, tetapi mama-mama para pengrajin noken diundang ke kampus untuk memberi pelatihan ke mahasiswa. Selanjutnya, akan diperkenalkan motif-motif baru yang didesain bersama mahasiswa sebagai karya-karya kreatif. Keterampilan membuat noken merupakan bagian dari prasayarat untuk menjadi sarjana. Sehingga setiap alumni bukan saja siap untuk bekerja, juga mereka siap terjun ke masyarakat.

Sebagai institusi pendidikan Islam, maka masjid menjadi bagian integral dalam pengelolaan pendidikan dan seluruh aktivitas perguruan tinggi. Masjid IAIN Sorong yang juga berfungsi sebagai laboratorium keagamaan tidak saja secara fisik ditempatkan di bagian paling depan tetapi juga menjadi pusat keagamaan yang terdepan dalam aktivitas keagamaan. Bahkan dalam 2 SKS mata kuliah Manajemen Masjid sebagai bagian kurikulum dikelola masjid. Perkuliahan dan seluruh aktivitas yang melingkupinya dilaksanakan di masjid. Sehingga masjid tidak hanya berfungsi ketika shalat lima waktu. 
Masjid juga menjalankan fungsi Unit Pengumpul Zakat. Penerimaan zakat dikembalikan untuk keperluan mahasiswa sebagai mustahiq. Dikelola pula waqaf tunai sebagai upaya untuk memberikan kesempatan kepada mahasiswa studi lanjut terutama di perguruan tinggi terkemuka dunia. Bukan hanya dengan memikirkan bagaimana mereka lulus dengan kompetensi tertentu tetapi daya dukung untuk memastikan mereka lulus dengan pembiayaan juga perlu dilakukan.

Sebelum lulus, setiap mahasiswa punya kesempatan untuk duduk selama satu semester di perguruan tinggi pilihan baik dalam negara maupun luar negara. Mata kuliah yang mereka tempuh di perguruan tinggi mitra, akan dikonversi menjadi mata kuliah yang sudah ditempuh di IAIN Sorong. Walau alumni IAIN Sorong memegang ijazah perguruan tinggi lokal tetapi mereka memiliki wawasan global, bahkan memiliki kesempatan unuk berjumpa dengan mahasiswa dan dosen di pelbagai perguruan tinggi antarbangsa.

Alumni bukan saja dijadikan sebagai sebuah prestise atas prestasi yang mereka raih setelah lulus. Walau selama ini justru tanpa tersapa sama sekali. Bagian yang perlu dilakukan sejak awal adalah menyiapkan mereka untuk berkiprah sampai ke pelosok dunia. Alumni juga terkait dengan kompetensi lulusan. Mereka dipersyaratkan untuk memenuhi kualifikasi minimum. Jangan sampai mereka kemudian tidak berterima di pelbagai komunitas karena kemampuan yang tidak memenuhi kualifikasi untuk bergaul di masyarakat. Alumni pulalah yang menjadi prioritas pertama untuk dijadikan sebagai bagian dari pengembangan kepegawaian dan juga pengembangan keilmuan kampus.

Mahasiswa pada tahun ketiga mereka sudah diberikan kesempatan untuk mengikuti presentasi pengelola beasiswa. Demikian pula mahasiswa penerima beasiswa Bidik Misi akan dipersiapkan untuk studi lanjut. Bahkan mereka boleh memilih mengikuti Program Sarjana Lanjut Magister (PSLM). Ketika duduk di program studi pilihan mereka, mahasiswa sudah dipersiapkan untuk sampai pada jenjang strata dua, sekaligus dengan penyiapan pendanaan yang memungkinkan untuk didapatkan.

IAIN Sorong di samping mengelola perguruan tinggi terbesar di Tanah Papua juga memiliki pangkalan data berupa katalog induk Papua. Sehingga semua karya-karya yang berkaitan dengan Papua dapat ditelusuri melalui katalog tersebut. Bahkan dengan 18 perguruan tinggi yang ada di Sorong Raya, mahasiswa dapat meminjam buku di semua perguruan tinggi tersebut cukup dengan menunjukkan kartu keanggotaan perpustakaan IAIN Sorong. Jika mahasiswa memerlukan buku tertentu untuk perkuliahan, cukup dengan rekomendasi dosen pengampu, perpustakaan IAIN Sorong akan memasukkan buku tersebut dalam pengadaan buku perpustakaan. Peruntukan perpustakaan tidak saja bagi mahasiswa dan warga IAIN Sorong tetapi dibuka untuk umum. Sehingga waktu pembukaan sampai pada pukul 24.00. Ini untuk mewadahi 
warga Sorong Raya untuk mengakses perpustakaan usai jam kerja. Di perpustakaan tersedia kantin dan juga vending machine untuk keperluan komsumsi para pengunjung perpustakaan.

Setiap bulan, dilangsungkan bedah buku bagi mahasiswa. Sementara dosen juga memperkenalkan buku-buku yang ditulisnya secara berkala pula. Ruangan khusus diskusi di perpustakaan IAIN Sorong harus dijadwalkan tiga bulan sebelumnya karena begitu maraknya kegiatan mahasiswa dan dosen sekaitan dengan penggunaan perpustakaan. Termasuk perkuliahan yang juga dilangsungkan di perpustakaan. Bahkan sebelum itu, mahasiswa sudah diwajibkan mengikuti kursus orientasi penggunaan perpustakaan. Mereka diperkenalkan teknis penelusuran literatur, penggunaan katalog, dan proses layanan yang tersedia di perpustakaan.

IAIN Sorong menjadi pusat untuk riset-riset terkait dengan kajian Papua. Tidak sebatas Papua Barat saja tetapi juga keseluruhan Tanah Papua. Riset tersebut terpublikasi di jurnal-jurnal yang bereputasi dan juga tersedia dalam pangkalan data yang bereputasi. Ketika mengetikkan kata Papua, maka selalu saja civitas akademika IAIN Sorong menjadi bagian dalam produksi pengetahuan itu. Dosen dan mahasiswa dengan kolaborasi pelbagai perguruan tinggi terkemuka dunia mengembangkan triple helix dimana riset tidak berhenti sampai publikasi semata tetapi juga menjadi referensi dalam penentuan kebijakan dan juga menjadi percakapan di tingkat nasional. Begitu pula riset-riset tersebut disitasi oleh kalangan akademik global.

\section{Apa yang Tantangan IAIN?}

Pendidikan tinggi Indonesia hadir dalam pelbagai bentuk. Tidak harus menjadi universitas sebagaimana dilakukan Institut Teknologi Bandung dan Institut Pertanian Bogor. Namun kiprahnya sama dengan perguruan tinggi. Bentuk yang lain seperti akademi komunitas yang mementingkan keberpihakan kepada masyarakat untuk menyediakan layanan pendidikan formal yang dapat diartikulasi ke jenjang dan juga lembaga lain.

Perguruan tinggi hadir dengan misinya masing-masing. Tetapi misi itu kemudian tidak perlu menjadi utopis atau hanya menjadi sebuah pajangan belaka karena tidak diiringi dengan tindakan-tindakan kecil. Atau bahkan institusi justru mengabaikan suara-suara yang sama sekali tidak mau didengarnya. Ketika itu terjadi, sesungguhnya perguruan tinggi tidak lagi menjadi sebuah percaturan ide tetapi lebih hanya menjadi kepemimpinan yang didasari oleh kekuasaan semata. Apalagi kalau hanya mengalokasikan pendanaan untuk kepentingan dirinya sendiri. Bukan untuk kepentingan warga kampus dan wilayah yang didiami.

Atau justru pendanaan habis pada aktivitas yang tidak konstekstual. Dihabiskan pada aktivitas yang justru tidak diperlukan sama sekali. Begitu pula dengan keluhan bahwa ketika institusi menjadi IAIN, jangan sampai perilaku dan atmosfir akademik sama seperti ketika masih 
STAIN. Tantangan demi tantangan tentu akan wujud tetapi semuanya justru menjadi kesempatan untuk mewujudkan harapan dengan kebersamaan dan kebersahajaan.

IAIN Sorong juga memiliki fasilitas ma'had sehingga siap untuk melakukan pengembangan pendidikan tinggi berbasis pondok pesantren (Bali, 2017). Perguruan tinggi dengan tetap mempertahankan tradisi keberagamaan (Wekke, Hermawanto, \& Ashrori, 2016). Ketika ini diwujudkan, maka tuduhan Husaini (2006) tidak berdasar belaka.

\section{Penutup}

Artikel ini merupakan setakat refleksi. Bisajadi ada hal-hal yang bisa diwujudkan namun adapula kendala yang mengiringinya. Terdapat dinamika tersendiri yang menjadi kendala dalam mewujudkan semua keinginan. Namun, pada yang sama bukan berarti bahwa taka da yang mustahil. Semua terbuka peluang untuk mewujudkannya, atau setakat hanya berhenti sampai di angan belaka dan akhirnya menjadi angin lalu.

\section{Daftar Pustaka}

Abbas, T., \& Wekke, I. S. (2019). Yang Datang Setelah Hujan: Sains-Agama Penerang Kegelapan. https://doi.org/10.31227/osf.io/nfx4v.

Bali, M. M. E. I. (2017). Perguruan tinggi Islam berbasis pondok pesantren. Al-tanzim: Jurnal Manajemen Pendidikan Islam, 1(2), 1-14.

Etzkowitz, H., \& Zhou, C. (2017). The triple helix: University-industry-government innovation and entrepreneurship. Routledge.

Husaini, A. (2006). Hegemoni Kristen-Barat dalam studi Islam di perguruan tinggi. Jakarta: Gema insani.

Kuraedah, S., Gunawan, F., Wekke, I. S., \& Hamuddin, B. (2018). Learning Environment Construction in Islamic Higher Education: Connecting the Puzzles of Ideas. IOP Conference Series: Earth and Environmental Science, 175(1). IOP Publishing.

Mujahidah, M., \& Wekke, I. S. (2019). Transformasi Perguruan Tinggi Keagamaan Islam Indonesia. https://doi.org/10.31227/osf.io/46evm.

Mulyono, M., \& Wekke, I. S. (2018). Academic and Culture Development Strategy Management for Islamic Higher Education In Indonesian. IOP Conference Series: Earth and Environmental Science, 175(1). IOP Publishing.

Wekke, I. S. (2017). Arabic Teaching and Learning Material in Higher Education of Muslim Community North Sulawesi. Dinamika Ilmu, 17(2), 175-189.

Wekke, I. S. (2018). Higher education governance of muslim minority: efforts to be part of nation's development. AKADEMIKA: Jurnal Pemikiran Islam, 23(1), 1-26.

Wekke, I. S. (2019). Menata Saat Kini untuk Masa Hadapan: Agenda Transformasi Dari STAIN Ke IAIN. https://doi.org/10.31227/osf.io/d83es.

Wekke, I. S., Hermawanto, A., \& Ashrori, M. (2016). Keberagamaan Mahasiswa Di Perguruan Tinggi Wilayah Minoritas Muslim. Ulul Albab, 17(2), 135.

Wekke, I. S., Rajindra, R., Pushpalal, D., Samad, M. A., Yani, A., \& Umam, R. (2019). Educational Institution on Responding Disasters in Palu of Indonesia. https://doi.org/10.31227/osf.io/drc8q. 